\title{
Intensive agricultural technologies of winter wheat cultivation in the Middle Volga region
}

\author{
Natalya P. Bakaeva*, Olga L. Saltykova, Nina Yu. Korzhavina, and Maxim S. Prikazchikov \\ Samara State Agrarian University, Kinel 446442, Samara region, Russia
}

\begin{abstract}
The article describes agricultural technologies increasing nitrate nitrogen content in the soil, crop yield, protein content and its fractional composition in winter wheat grain in the Middle Volga region. An economic and energy assessment of the effectiveness of winter wheat cultivation is provided for various predecessors, methods of primary tillage and fertilizing. Long-term studies were carried out on the fields of the Department of Agriculture, the laboratory "Agroecology" of Samara State Agricultural Academy. When cultivating winter wheat using the black fallow method, without autumn mechanical tillage with double application of nitrogen fertilizing, the highest yield indicators $(2.79 \mathrm{t} / \mathrm{ha})$, protein content of $13.12 \%$, the maximum net income, profitability of $92 \%$ and energy efficiency were achieved. The energy efficiency coefficient in crops was the largest with the lowest energy coefficient in proteins.
\end{abstract}

\section{Introduction}

In the grain balance of Samara region, the most valuable food crop is wheat whose high-quality grain is widely used.

An increase in yield and grain quality of winter wheat is possible on the basis of intensification of agriculture whose leading factors are predecessors, methods of primary tillage and fertilizers [1-3].

The search for ways to increase crop yield taking into account the energy and economic state of agricultural production is the main problem of agriculture [4]. Research should be aimed at developing such methods and systems of tillage that would contribute to the preservation of soil fertility, the creation of optimal conditions for the growth and development of plants, providing a high crop yield [5, 6]. At present, new technologies for the cultivation of grain crops based on the use of minimum tillage are becoming more widespread [7-12].

\section{Materials and methods}

\subsection{Objects}

The study was conducted in the central zone of Samara region in 2004-2007, on the experimental fields of the Department of Agriculture, the laboratory "Agroecology" of Samara State Agricultural Academy.

Meteorological conditions were contrasting, the hydrothermal coefficient ranged from 0.42 to 1.20 with an average annual value of 0.83 .

According to the Ust-Kinel weather station, the agricultural year 2003-2004 was characterized by increased temperatures and an abundance of precipitation - which was 1.1-1.3 times higher than the long-term norm, the HTC was 0.90. The weather conditions of the 2004-2005 agricultural year were characterized by an increased temperature regime and a lack of precipitation (6.4 times less than the norm); the HTC was 0.42 lower than the average annual values. The agricultural year 2005-2006 was characterized by an increased temperature regime and heavy rainfall, the HTC was 1.20. The weather conditions of the 2006-2007 agricultural year were characterized by a temperature regime close to long-term average values and heavy rainfall; the HTC was 0.68 .

The soil of the experimental plot is a typical medium humus, medium heavy loamy chernozem with a medium reaction $(\mathrm{pH})$ close to neutral and average humus content.

The object was winter wheat Malachite cultivated using the black, seed (peas) and green (peas and oats) fallow methods method. The following tillage systems were used: plowing to a depth of $25-27 \mathrm{~cm}$, loosening to a depth of 10-12 cm and no autumn mechanical tillage.

Winter wheat was treated with herbicides in the phase of shooting (at a concentration of $0.45 \mathrm{l} / \mathrm{ha}$ ).

The following doses and dates of nitrogen fertilizing were studied: 1. without fertilizers (control); 2. root treatment with ammonium nitrate at a dose of $30 \mathrm{~kg} / \mathrm{ha}$ in the phase of tillering, N30; 3. Root treatment with ammonium nitrate at a dose of $30 \mathrm{~kg} / \mathrm{ha}$ in the tillering phase and foliar treatment with urea at a dose of $30 \mathrm{~kg} / \mathrm{ha}, \mathrm{N}_{30}+\mathrm{N}_{30}$.

The plot area was $1200 \mathrm{~m}^{2}$. The experiments were carried out three times.

The objective was to improve the agricultural technology of winter wheat cultivation in order to

* Corresponding author: bakaevanp@ mail.ru 
increase yield and protein content in grain in terms of economic and energy efficiency in the Middle Volga region.

The objective was to study the influence of predecessors, basic tillage methods and fertilizer techniques on productivity, protein accumulation, gluten fractions, economic and energy efficiency.

\subsection{Methods}

Soil moisture was determined by the thermostatweighting method to a depth of $1 \mathrm{~m}$ for every $10 \mathrm{~cm}$. Soil density was determined by the method of cylinders, soil samples were taken on all the studied options to a depth of $30 \mathrm{~cm}$. Samples were taken before sowing and harvesting. Nitrate nitrogen was determined by the disulfophenol method according to B.P. Pleshkov. Harvest accounting was carried out by continuous harvesting of the plots with a combine, the moisture was $14 \%$; conditions for the content of weed impurities were basic. The selection of plants for analysis was carried out according to the method proposed by A.I. Ermakov, protein fractions of wheat grain were isolated according to the method by H.N. Pochinok based on the unequal solubility of proteins in various solvents. The colorimetric method described by G.A. Kochetov determined the content of protein and its fractions $[13,14]$. The experimental data were processed by the analysis of variance according to B.A. Dospekhov (1985) using STATISTICA [15]. Calculations of economic and energy indicators were carried out on the basis of technological maps according to the guidelines [16].

\section{Results}

Soil moisture is an important factor affecting the growth and development of plants. In spring and by the time of wheat harvest, the soil moisture in the layer of $0-30 \mathrm{~cm}$ was determined. In the beginning of the growing season and before harvesting, the soil moisture was higher in black fallow. The main tillage methods and the use of fertilizers did not significantly affect the soil moisture.

In the beginning of the growing season, in all the variants, the humidity was higher than before harvesting and amounted to $28.0-33.5 \%$ for black fallow, 23.0-32.7 \% for seed fallow and 27.3-28.3\% - for green fallow. By the time of harvesting, soil moisture decreased to $14-18 \%$.

The main property that determines water, air and thermal regimes of soils, orientation and intensity of microbiological processes, mobilization of nutrients and nutritional conditions of plants is density of the composition of the arable soil layer.

Over the years of research, the soil density in the arable layer was $1.11 \mathrm{~g} / \mathrm{cm}^{3}$; the optimal values for winter wheat are $1.1-1.3 \mathrm{~g} / \mathrm{cm}^{3}$. Small changes in density indicators depended on soil moisture. In 2007 characterized by atmospheric drought at the end of the growing season, a slight increase in soil density was observed before harvesting for the black fallow $\left(1.18 \mathrm{~g} / \mathrm{cm}^{3}\right)$ and green fallow $\left(1.14 \mathrm{~g} / \mathrm{cm}^{3}\right)$ methods. During the years of research, soil density values were optimal and predecessors did not significantly affect its density.

Among the basic nutrients required for the growth and development of plants, nitrogen is crucial. The nitrogen regime is the most unstable and depends on weather conditions, crop rotation, fertilizers and tillage mehtods.

The content of nitrate nitrogen was determined before sowing. Its value was $11.1 \mathrm{mg} / \mathrm{kg}$ and in various phases of plant development (Table 1). During the tillering period in the variants without fertilizer application, the highest nitrate nitrogen content was for black fallow $(23.5 \mathrm{mg} / \mathrm{kg})$, slightly lower values were observed for green falow $(21.8 \mathrm{mg} / \mathrm{kg}$ ), and the lowest values were observed for seed fallow $(20.1 \mathrm{mg} / \mathrm{kg})$. Root treatment with nitrogen fertilizer (N30) in the tillering phase contributed to an increase in nitrate nitrogen by 1.8 times. At the grain formation stage, the content of nitrate nitrogen decreased by 2.4 times in the variants without fertilizing, both for black and green fallowing methods. The application of nitrogen in the tillering phase doubled the soil nitrogen content in all experimental variants. The second fertilizing with nitrogen fertilizer increased nitrogen in all variants. By the end of the growing season of, before harvesting, the content of nitrate nitrogen increased 1.5 times.

When comparing soil cultivation options by nitrate nitrogen content, plowing by $25-27 \mathrm{~cm}$ contributed to a higher content of nitrate nitrogen; this dynamics was observed for all fallow precursors, and remained for single and double application of nitrogen fertilizers.

Integrating indicators of the influence of predecessors, primary tillage methods, and fertilizers are yield, protein content and its fractional composition [17].

The yield in black fallow was higher by $0.75 \mathrm{t} / \mathrm{ha}$ and $0.17 \mathrm{t} / \mathrm{ha}$, respectively. The weight of 1000 grains was $44.27 \mathrm{~g}$ and $44.53 \mathrm{~g}$ for the black fallow, $44.23 \mathrm{~g}$ - for the green fallow. The highest yield was obtained in the variants without autumn mechanical treatment when applying nitrogen fertilizers in the amount of twice $30 \mathrm{~kg} / \mathrm{ha}$ : for black fallow $-2.79 \mathrm{t} / \mathrm{ha}$, for seed fallow $2.25 \mathrm{t} / \mathrm{ha}$ and for green green fallow $-2.60 \mathrm{t} / \mathrm{ha}$. The maximum mass of 1000 grains was $46.6 \mathrm{~g}$ (Table 2).

The most important biochemical indicators used to evaluate the quality of wheat grain are the protein content and its fractional composition [18-20].

Most of protein is synthesized as a result of the outflow of nitrogenous substances from the leaves accumulated by the beginning of the grain formation.

The accumulation of total protein in the leaves of winter wheat was $2.83 \%$ in the tillering phase, $4.97 \%$ in the shooting phase, and $6.19 \%$ - in the earing phase. The nitrogen content increased by the earing phase. The provision of plants with nitrogen contributed to highest protein content in the heading phase when using the black fallow method with plowing $(1.16 \%)$ and loosening the soil $(1.14 \%)$. 
Table 1. The content of nitrate nitrogen in the soil layer of 0-30 $\mathrm{cm}$ under wheat depending on the predecessor, methods of basic tillage and fertilizers, on average over the years of research

\begin{tabular}{|c|c|c|c|c|}
\hline \multirow[t]{2}{*}{ Soil treatment } & \multirow[t]{2}{*}{ Fertilizers } & \multicolumn{3}{|c|}{$\begin{array}{c}\text { Average values } \\
\mathrm{NO}_{3} \text { content in soil by the } \\
\text { phases, } \mathrm{mg} / \mathrm{kg}\end{array}$} \\
\hline & & tillering & $\begin{array}{c}\text { grain } \\
\text { formation }\end{array}$ & $\begin{array}{c}\text { before } \\
\text { harvesting }\end{array}$ \\
\hline \multicolumn{5}{|c|}{ Black fallow } \\
\hline \multirow{3}{*}{$\begin{array}{l}\text { Fallowing } \\
\text { to a depth } \\
\text { of } 25-27 \mathrm{~cm}\end{array}$} & $\begin{array}{l}\text { Without } \\
\text { fertilizers }\end{array}$ & 23.53 & 9.88 & 14.71 \\
\hline & $\mathrm{N}_{30}$ & 41.30 & 18.82 & 22.21 \\
\hline & $\mathrm{N}_{30}+\mathrm{N}_{30}$ & 43.74 & 20.74 & 22.80 \\
\hline \multirow{3}{*}{$\begin{array}{l}\text { Loosening } \\
\text { to a depth } \\
\text { of } 10-12 \mathrm{~cm}\end{array}$} & $\begin{array}{c}\text { Without } \\
\text { fertilizers }\end{array}$ & 24.37 & 9.57 & 13.68 \\
\hline & $\mathrm{N}_{30}$ & 39.77 & 17.64 & 19.74 \\
\hline & $\mathrm{N}_{30}+\mathrm{N}_{30}$ & 41.18 & 19.03 & 21.64 \\
\hline \multirow{3}{*}{$\begin{array}{c}\text { Without } \\
\text { autumn } \\
\text { mechanical } \\
\text { treatment }\end{array}$} & $\begin{array}{l}\text { Without } \\
\text { fertilizers }\end{array}$ & 19.98 & 8.59 & 10.72 \\
\hline & $\mathrm{N}_{30}$ & 34.02 & 13.07 & 16.99 \\
\hline & $\mathrm{N}_{30}+\mathrm{N}_{30}$ & 35.59 & 14.79 & 18.60 \\
\hline \multicolumn{2}{|c|}{ Average } & 33.72 & 14.68 & 17.80 \\
\hline \multicolumn{5}{|c|}{ Seed fallow } \\
\hline \multirow{3}{*}{$\begin{array}{l}\text { Fallowing } \\
\text { to a depth } \\
\text { of } 25-27 \mathrm{~cm}\end{array}$} & $\begin{array}{c}\text { Without } \\
\text { fertilizers }\end{array}$ & 20.09 & 9.41 & 13.48 \\
\hline & $\mathrm{N}_{30}$ & 37.01 & 17.30 & 18.94 \\
\hline & $\mathrm{N}_{30}+\mathrm{N}_{30}$ & 40.09 & 18.66 & 20.01 \\
\hline \multirow{3}{*}{$\begin{array}{l}\text { Loosening } \\
\text { to a depth } \\
\text { of } 10-12 \mathrm{~cm}\end{array}$} & $\begin{array}{l}\text { Without } \\
\text { fertilizers }\end{array}$ & 19.41 & 9.98 & 12.56 \\
\hline & $\mathrm{N}_{30}$ & 35.40 & 16.44 & 18.35 \\
\hline & $\mathrm{N}_{30}+\mathrm{N}_{30}$ & 37.04 & 18.82 & 18.46 \\
\hline \multirow{3}{*}{$\begin{array}{l}\text { Without } \\
\text { autumn } \\
\text { mechanical } \\
\text { treatment }\end{array}$} & $\begin{array}{c}\text { Without } \\
\text { fertilizers }\end{array}$ & 16.71 & 8.57 & 10.44 \\
\hline & $\mathrm{N}_{30}$ & 32.21 & 13.08 & 13.77 \\
\hline & $\mathrm{N}_{30}+\mathrm{N}_{30}$ & 32.71 & 13.78 & 13.21 \\
\hline \multicolumn{2}{|c|}{ Average } & 30.07 & 14.00 & 15.50 \\
\hline \multicolumn{5}{|c|}{ Green fallow } \\
\hline \multirow{3}{*}{$\begin{array}{l}\text { Fallowing } \\
\text { to a depth } \\
\text { of } 25-27 \mathrm{~cm}\end{array}$} & $\begin{array}{c}\text { Without } \\
\text { fertilizers }\end{array}$ & 21.80 & 9.05 & 14.00 \\
\hline & $\mathrm{N}_{30}$ & 42.31 & 18.38 & 20.42 \\
\hline & $\mathrm{N}_{30}+\mathrm{N}_{30}$ & 41.65 & 17.69 & 20.75 \\
\hline \multirow{3}{*}{$\begin{array}{l}\text { Loosening } \\
\text { to a depth } \\
\text { of } 10-12 \mathrm{~cm}\end{array}$} & $\begin{array}{c}\text { Without } \\
\text { fertilizers }\end{array}$ & 20.16 & 8.65 & 12.64 \\
\hline & $\mathrm{N}_{30}$ & 38.31 & 17.76 & 19.12 \\
\hline & $\mathrm{N}_{30}+\mathrm{N}_{30}$ & 37.07 & 16.72 & 20.01 \\
\hline \multirow{3}{*}{$\begin{array}{l}\text { Without } \\
\text { autumn } \\
\text { mechanical } \\
\text { treatment }\end{array}$} & $\begin{array}{l}\text { Without } \\
\text { fertilizers }\end{array}$ & 16.91 & 8.47 & 10.50 \\
\hline & $\mathrm{N}_{30}$ & 34.52 & 15.23 & 15.65 \\
\hline & $\mathrm{N}_{30}+\mathrm{N}_{30}$ & 34.95 & 14.76 & 15.28 \\
\hline \multicolumn{2}{|c|}{ Average } & 31.96 & 14.08 & 16.60 \\
\hline
\end{tabular}

The nitrogen content for black fallow was $2.3 \%$, for seed fallow was $2.2 \%$ and for green fallow was $2.1 \%$. When applying root treatment with nitrogen (N30) in the tillering phase, the nitrogen content was $2.2 \%$, which is $6.3 \%$ higher than in the variant without fertilizers. Double application of nitrogen at a dose of $30 \mathrm{~kg} / \mathrm{ha}$ increased the nitrogen content by $8.4 \%$. The highest nitrogen content (2.42-2.44\%) was observed for black fallow when plowing to a depth of $25-27 \mathrm{~cm}$ and loosening the soil to a depth of 10-12 cm when applying nitrogen fertilizing twice.
Table 2. The influence of predecessors, tillage methods and fertilizers on the yield of winter wheat, protein and nitrogen content in the grain during full ripeness, and the removal of nitrogen (on average for 2004-2007).

\begin{tabular}{|c|c|c|c|c|c|}
\hline Soil treatment & Fertilizers & 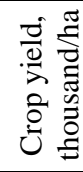 & 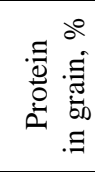 & 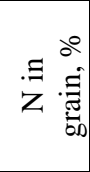 & 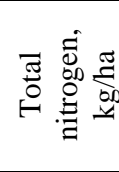 \\
\hline \multicolumn{6}{|c|}{ Black fallow } \\
\hline \multirow{3}{*}{$\begin{array}{l}\text { Fallowing } \\
\text { to a depth } \\
\text { of } 25-27 \mathrm{~cm}\end{array}$} & $\begin{array}{l}\text { Without } \\
\text { fertilizers }\end{array}$ & 2.37 & 12.74 & 2.24 & 125.80 \\
\hline & $\mathrm{N}_{30}$ & 2.55 & 13.65 & 2.39 & 155.30 \\
\hline & $\mathrm{N}_{30}+\mathrm{N}_{30}$ & 2.59 & 13.92 & 2.44 & 163.70 \\
\hline \multirow{3}{*}{$\begin{array}{l}\text { Loosening } \\
\text { to a depth } \\
\text { of } 10-12 \mathrm{~cm}\end{array}$} & $\begin{array}{c}\text { Without } \\
\text { fertilizers }\end{array}$ & 2.24 & 12.61 & 2.21 & 110.90 \\
\hline & $\mathrm{N}_{30}$ & 2.43 & 13.36 & 2.34 & 138.30 \\
\hline & $\mathrm{N}_{30}+\mathrm{N}_{30}$ & 2.50 & 13.80 & 2.42 & 132.50 \\
\hline \multirow{3}{*}{$\begin{array}{c}\text { Without } \\
\text { autumn } \\
\text { mechanical } \\
\text { treatment }\end{array}$} & $\begin{array}{c}\text { Without } \\
\text { fertilizers }\end{array}$ & 2.47 & 12.10 & 2.12 & 129.40 \\
\hline & $\mathrm{N}_{30}$ & 2.70 & 13.00 & 2.28 & 166.30 \\
\hline & $\mathrm{N}_{30}+\mathrm{N}_{30}$ & 2.79 & 13.12 & 2.30 & 179.10 \\
\hline \multicolumn{6}{|c|}{ Seed fallow } \\
\hline \multirow{3}{*}{$\begin{array}{l}\text { Fallowing } \\
\text { to a depth } \\
\text { of } 25-27 \mathrm{~cm}\end{array}$} & $\begin{array}{l}\text { Without } \\
\text { fertilizers }\end{array}$ & 1.48 & 11.84 & 2.07 & 45.30 \\
\hline & $\mathrm{N}_{30}$ & 1.71 & 12.90 & 2.26 & 66.00 \\
\hline & $\mathrm{N}_{30}+\mathrm{N}_{30}$ & 1.86 & 13.58 & 2.38 & 82.40 \\
\hline \multirow{3}{*}{$\begin{array}{l}\text { Loosening } \\
\text { to a depth } \\
\text { of } 10-12 \mathrm{~cm}\end{array}$} & $\begin{array}{l}\text { Without } \\
\text { fertilizers }\end{array}$ & 1.43 & 11.91 & 2.08 & 42.50 \\
\hline & $\mathrm{N}_{30}$ & 1.62 & 12.61 & 2.21 & 57.90 \\
\hline & $\mathrm{N}_{30}+\mathrm{N}_{30}$ & 1.73 & 13.14 & 2.31 & 69.00 \\
\hline \multirow{3}{*}{$\begin{array}{c}\text { Without } \\
\text { autumn } \\
\text { mechanical } \\
\text { treatment }\end{array}$} & $\begin{array}{c}\text { Without } \\
\text { fertilizers }\end{array}$ & 1.84 & 11.34 & 1.99 & 67.30 \\
\hline & $\mathrm{N}_{30}$ & 2.03 & 12.29 & 2.16 & 88.90 \\
\hline & $\mathrm{N}_{30}+\mathrm{N}_{30}$ & 2.25 & 12.78 & 2.24 & 113.40 \\
\hline \multicolumn{6}{|c|}{ Green fallow } \\
\hline \multirow{3}{*}{$\begin{array}{l}\text { Fallowing } \\
\text { to a depth } \\
\text { of } 25-27 \mathrm{~cm}\end{array}$} & $\begin{array}{c}\text { Without } \\
\text { fertilizers }\end{array}$ & 2.32 & 11.79 & 2.07 & 111.36 \\
\hline & $\mathrm{N}_{30}$ & 2.43 & 12.44 & 2.18 & 128.50 \\
\hline & $\mathrm{N}_{30}+\mathrm{N}_{30}$ & 2.33 & 12.49 & 2.19 & 118.83 \\
\hline \multirow{3}{*}{$\begin{array}{l}\text { Loosening } \\
\text { to a depth } \\
\text { of } 10-12 \mathrm{~cm}\end{array}$} & $\begin{array}{c}\text { Without } \\
\text { fertilizers }\end{array}$ & 2.20 & 11.47 & 2.01 & 97.24 \\
\hline & $\mathrm{N}_{30}$ & 2.38 & 11.89 & 2.09 & 118.30 \\
\hline & $\mathrm{N}_{30}+\mathrm{N}_{30}$ & 2.21 & 12.18 & 2.14 & 104.50 \\
\hline \multirow{3}{*}{$\begin{array}{l}\text { Without } \\
\text { autumn } \\
\text { mechanical } \\
\text { treatment }\end{array}$} & $\begin{array}{c}\text { Without } \\
\text { fertilizers }\end{array}$ & 2.35 & 11.19 & 1.96 & 108.30 \\
\hline & $\mathrm{N}_{30}$ & 2.54 & 11.83 & 2.07 & 133.60 \\
\hline & $\mathrm{N}_{30}+\mathrm{N}_{30}$ & 2.46 & 11.90 & 2.08 & 125.90 \\
\hline
\end{tabular}

The dispersion analysis accompanied by calculation of NDS05 showed that all the results of the experiment are reliable.

The protein content in winter wheat for black fallow was 4.9 and $9.4 \%$ higher than for seed and green fallows. With an increase in the protein content of grain, depending on the growing conditions, the content of all protein fractions in increases: most of all prolamins, fewer glutelins and even less albumin and globulins. The content of gluten fractions averaged 5.55 and $2.99 \%$.

The highest protein content was observed when plowing to a depth of $25-27 \mathrm{~cm}$ and loosening to a depth of $10-12 \mathrm{~cm}$ ( 5 and $3 \%$ higher, respectively). When nitrogen was added twice, the content of prolamin and glutelin fractions increased and averaged 5.55 and $3.02 \%$, respectively. Under the influence of nitrogen 
fertilizers, the protein concentration increased as a result of increased protein synthesis.

The protein content with a double application of nitrogen was higher by 9.0 and $15.4 \%$ than without treatment.

In the phase of complete ripeness, the protein content for black fallow was 4.9 and $9.4 \%$ higher than for seed and green fallow. The highest protein content was observed when plowing to a depth of $25-27 \mathrm{~cm}$ and loosening to a depth of $10-12 \mathrm{~cm}(2.0-5.6 \%$ higher than without autumn mechanical tillage). Double application of nitrogen increased the protein content for black fallow by $8.3 \%$, for seed fallow - by $11.2 \%$, and for green fallow - by $5.8 \%$.

The total nitrogen content for black fallow amounted to $144.59 \mathrm{~kg} / \mathrm{ha}$, for seed fallow $-70.3 \mathrm{~kg} / \mathrm{ha}$, for green fallow $-116.28 \mathrm{~kg} / \mathrm{ha}$. In the variant without fertilizers, the nitrogen content amounted to $93.12 \mathrm{~kg} / \mathrm{ha}$. The use of nitrogen during the tillering phase increased the nitrogen content by $23.89 \mathrm{~kg} / \mathrm{ha}$, and their double application increased the nitrogen content by $27.92 \mathrm{~kg} / \mathrm{ha}$. The greatest nitrogen content was observed in the variant without autumn mechanical tillage - $123.58 \mathrm{~kg} / \mathrm{ha}$, which is $10 \%$ higher than when plowing to a depth of $25-27 \mathrm{~cm}$, and by $22 \%$ - when soil loosening to a depth of $10-12 \mathrm{~cm}$.

The applied agricultural technologies in the cultivation of winter wheat should be agronomically, cost-effective and energy-efficient.

On average, calculations of the economic efficiency of winter wheat cultivation, depending on the predecessors, primary tillage methods and fertilizers showed that the sum of production costs for black fallow was less than for seed and green ones. The maximum production costs were observed for all fallow predecessors when plowing to a depth of $25-27 \mathrm{~cm}$, and the minimum - without autumn mechanical tillage. The use of nitrogen fertilizers contributed to an increase in grain yield. As a result, the value of the main products increased. When cultivating winter wheat using the black fallow method with nitrogen treatment, the cost of grain per hectare was 7.0-8.5 \%, and with double application of fertilizers, it was 8.5-11.5\% higher than without fertilizers. The same pattern was observed for black fallow and green fallow methods. The lowest cost of 1 ton of winter wheat grain was noted without autumn mechanical tillage using nitrogen treatment.

The maximum net income and profitability $(92.34 \%)$ were obtained when cultivating winter wheat using the black fallow method without autumn mechanical tillage and with double application of nitrogen.

There is a contradiction between the high economic effect and deterioration of the humus content.

The calculations show that when cultivating winter wheat using the black fallow and seed fallow methods, there was a negative humus balance for all tillage and fertilizer application levels, and a positive balance - for green fallow. With a positive humus balance, it is not necessary to apply organic fertilizers to compensate for the loss of humus in the soil.

The environmental and economic assessment of winter wheat cultivation showed that production costs, taking into account the cost of restoring soil fertility, amounted to 7.04-8.57 thousand rubles/ha for the black fallow method, and 9.28-11,03 thousand rubles/ha for the seed fallow method. The maximum net income was obtained both for the black fallow and for the seed one without autumn mechanical tillage with a double application of nitrogen fertilizers. At the same time, the level of total profitability for the black fallow amounted to $66.79 \%$, and for the seed fallow $-46.74 \%$, which is 1.3-2.4 times less compared to the economic estimate. The environmental and economic efficiency of winter wheat cultivation for the green fallow is adequate to the economic one, since it does not require investment of additional funds to restore soil fertility; the profitability is $32.89 \%$.

The energy efficiency of winter wheat cultivation showed a positive balance of energy consumption (Table. 3)

Calculations of the energy efficiency of winter wheat cultivation showed that when using the black fallow method, the energy in crops was 1.0-1.6 times greater than when using the seed and green fallow methods. The energy in protein of wheat grains amounted to 3.76-4.85 thousand $\mathrm{MJ} / \mathrm{ha}$ for the black fallow method, 2.26-3.83 thousand $\mathrm{MJ} / \mathrm{ha}$ - when using the seed fallow method, and 3.37-4.21 thousand. MJ/ha - when using the green fallow method. For all the predecessors, the variant without autogenous soil cultivation and with double application of nitrogen fertilizers showed the greatest energy accumulation in crops and protein, as well as the highest net energy income, and the lowest energy cost.

The greatest expenditures of anthropogenic energy were observed for plowing, and the smallest ones without autumn tillage. The nitrogen fertilizing increased the cost of anthropogenic energy for black fallow by 16 $\%$, seed fallow - by $15 \%$, and green fallow - by $18 \%$.

The energy efficiency coefficient in crops for all experimental options was above zero; the agricultural technologies of winter wheat cultivation can be considered energy-efficient

The maximum coefficient of energy efficiency in crops and the lowest coefficient of energy consumption in protein of winter wheat grains were obtained without autumn mechanical tillage. The black fallow variant proved to be the most energy-efficient without autumn mechanical tillage with double application of nitrogen fertilizers; the energy efficiency coefficient in crops was the highest - 2.18, and the energy consumption coefficient in protein was the lowest - 5.31.

\section{Discussion}

The agricultural technologies showed that at the beginning of the growing season and before harvesting, the soil moisture was higher for black fallow. The main tillage methods and the use of fertilizers did not significantly affect the soil moisture. Indicators of soil density for all variants of the experiment did not go beyond the optimal values for winter wheat. Black fallow, plowing and the use of nitrogen fertilizers contributed to an increase in the content of nitrate nitrogen in the arable layer of the soil. 
Table 3. Energy efficiency of winter wheat cultivation depending on the predecessor, tillage methods and fertilizers (on average over the years of research)

\begin{tabular}{|c|c|c|c|c|c|c|c|}
\hline \multirow{3}{*}{ Soil treatment } & \multirow{3}{*}{ Fertilizers } & \multicolumn{6}{|c|}{ Indicators } \\
\hline & & \multicolumn{2}{|c|}{$\begin{array}{c}\text { Accumulated energy, } \\
\text { thousand } \mathrm{MJ} / \mathrm{ha}\end{array}$} & \multirow{2}{*}{$\begin{array}{c}\text { Antopogenic } \\
\text { energy costs, } \\
\text { thousand MJ/ha }\end{array}$} & \multirow{2}{*}{$\begin{array}{c}\text { Energy gain in } \\
\text { crops, thousand } \\
\mathrm{MJ} / \mathrm{ha}\end{array}$} & \multicolumn{2}{|c|}{$\begin{array}{c}\text { Energy cost } \\
\text { thousand } \mathrm{MJ} / \mathrm{t}\end{array}$} \\
\hline & & in crops & in protein & & & in crops & in protein \\
\hline \multicolumn{8}{|c|}{ Black fallow } \\
\hline \multirow{3}{*}{$\begin{array}{l}\text { Fallowing } \\
\text { to a depth } \\
\text { of } 25-27 \mathrm{~cm}\end{array}$} & Without fertilizers & 31.54 & 4.10 & 16.92 & 14.62 & 7.14 & 133.22 \\
\hline & $\mathrm{N}_{30}$ & 33.94 & 4.74 & 19.32 & 14.62 & 7.58 & 142.06 \\
\hline & $\mathrm{N}_{30}+\mathrm{N}_{30}$ & 34.47 & 4.82 & 19.70 & 14.77 & 7.61 & 140.71 \\
\hline \multirow{3}{*}{$\begin{array}{l}\text { Loosening } \\
\text { to a depth } \\
\text { of } 10-12 \mathrm{~cm}\end{array}$} & Without fertilizers & 29.81 & 3.76 & 15.32 & 14.49 & 6.84 & 121.59 \\
\hline & $\mathrm{N}_{30}$ & 32.34 & 4.33 & 17.86 & 14.48 & 7.35 & 133.28 \\
\hline & $\mathrm{N}_{30}+\mathrm{N}_{30}$ & 33.28 & 4.60 & 18.30 & 14.98 & 7.32 & 132.61 \\
\hline \multirow{3}{*}{$\begin{array}{c}\text { Without autumn } \\
\text { mechanical } \\
\text { treatment }\end{array}$} & Without fertilizers & 32.88 & 3.98 & 14.30 & 18.58 & 5.79 & 118.18 \\
\hline & $\mathrm{N}_{30}$ & 35.94 & 4.67 & 16.82 & 19.12 & 6.23 & 129.38 \\
\hline & $\mathrm{N}_{30}+\mathrm{N}_{30}$ & 37.13 & 4.85 & 17.01 & 20.12 & 6.10 & 129.85 \\
\hline \multicolumn{8}{|c|}{ Seed fallow } \\
\hline \multirow{3}{*}{$\begin{array}{c}\text { Fallowing } \\
\text { to a depth } \\
\text { of } 25-27 \mathrm{~cm}\end{array}$} & Without fertilizers & 19.70 & 2.32 & 19.58 & 0.12 & 13.23 & 165.93 \\
\hline & $\mathrm{N}_{30}$ & 22.76 & 2.94 & 22.36 & 0.40 & 13.08 & 173.33 \\
\hline & $\mathrm{N}_{30}+\mathrm{N}_{30}$ & 24.76 & 3.37 & 22.55 & 2.21 & 12.12 & 165.81 \\
\hline \multirow{3}{*}{$\begin{array}{l}\text { Loosening } \\
\text { to a depth } \\
\text { of } 10-12 \mathrm{~cm}\end{array}$} & Without fertilizers & 19.03 & 2.26 & 18.23 & 0.80 & 12.75 & 153.19 \\
\hline & $\mathrm{N}_{30}$ & 21.56 & 2.82 & 21.02 & 0.54 & 12.98 & 160.46 \\
\hline & $\mathrm{N}_{30}+\mathrm{N}_{30}$ & 23.03 & 3.01 & 21.20 & 1.83 & 12.25 & 161.83 \\
\hline \multirow{3}{*}{$\begin{array}{c}\text { Without autumn } \\
\text { mechanical } \\
\text { treatment }\end{array}$} & Without fertilizers & 24.49 & 2.76 & 17.30 & 7.19 & 9.40 & 153.10 \\
\hline & $\mathrm{N}_{30}$ & 27.02 & 3.33 & 20.13 & 6.89 & 9.92 & 163.66 \\
\hline & $\mathrm{N}_{30}+\mathrm{N}_{30}$ & 29.95 & 3.83 & 20.35 & 9.60 & 9.04 & 158.98 \\
\hline \multicolumn{8}{|c|}{ Green fallow } \\
\hline \multirow{3}{*}{$\begin{array}{l}\text { Fallowing } \\
\text { to a depth } \\
\text { of } 25-27 \mathrm{~cm}\end{array}$} & Without fertilizers & 30.88 & 3.64 & 17.23 & 13.65 & 7.43 & 146.02 \\
\hline & $\mathrm{N}_{30}$ & 32.34 & 4.01 & 20.14 & 12.20 & 8.29 & 162.42 \\
\hline & $\mathrm{N}_{30}+\mathrm{N}_{30}$ & 33.54 & 4.18 & 20.44 & 13.10 & 8.11 & 163.52 \\
\hline \multirow{3}{*}{$\begin{array}{c}\text { Loosening } \\
\text { to a depth } \\
\text { of } 10-12 \mathrm{~cm} \\
\end{array}$} & Without fertilizers & 29.28 & 3.37 & 16.80 & 12.48 & 7.64 & 146.09 \\
\hline & $\mathrm{N}_{30}$ & 31.68 & 3.76 & 19.63 & 12.05 & 8.25 & 164.96 \\
\hline & $\mathrm{N}_{30}+\mathrm{N}_{30}$ & 33.14 & 4.21 & 20.00 & 13.15 & 8.03 & 157.48 \\
\hline \multirow{3}{*}{$\begin{array}{c}\text { Without autumn } \\
\text { mechanical } \\
\text { treatment }\end{array}$} & Without fertilizers & 31.28 & 3.5 & 16.08 & 15.20 & 6.84 & 143.57 \\
\hline & $\mathrm{N}_{30}$ & 33.81 & 3.99 & 19.05 & 14.76 & 7.50 & 170.09 \\
\hline & $\mathrm{N}_{30}+\mathrm{N}_{30}$ & 34.61 & 4.11 & 19.50 & 15.11 & 7.50 & 165.25 \\
\hline
\end{tabular}

The yield of winter wheat, the protein content and its fractional composition are integrating indicators of the influence of predecessors, the methods of primary tillage and fertilizers. The highest grain yield of winter wheat was observed for the black fallow method without autumn mechanical tillage with a double application of nitrogen fertilizing of $30 \mathrm{~kg} / \mathrm{ha}(2.79 \mathrm{t} / \mathrm{ha}$ with a mass of 1000 grains equal to $46.6 \mathrm{~g}$ ).

The provision of plants with nitrogen contributed to the highest protein content in the leaves when using the black fallow method and plowing to a depth of 25-27 cm and loosening to a depth of $10-12 \mathrm{~cm}$. In the phase of complete ripeness of winter wheat, the protein content was the highest for the black fallow when plowing and loosening the soil.

When cultivating winter wheat using the black fallow method without autumn mechanical tillage with double application of nitrogen fertilizers, the maximum net income and profitability of $92 \%$ were obtained.

The energy efficiency of winter wheat cultivation in all experiment variants showed a positive balance of energy consumption. The energy efficiency coefficient in crops was above zero for all the options; the agricultural technologies of winter wheat cultivation can be considered energy efficient.
The black fallow variant proved to be the most energy-efficient without autumn mechanical tillage with double application of nitrogen fertilizers; the energy efficiency coefficient in crops was the highest -2.18 , and the energy consumption coefficient in protein was the lowest -5.31 .

\section{Conclusion}

The formation of a high yield and protein content is the end result of a number of complex physiological and biochemical processes influenced by various agricultural technologies. When cultivating winter wheat using the black fallow method, without autumn mechanical tillage with double application of nitrogen fertilizing (N30 + $\mathrm{N} 30$ ) - root treatment with ammonium nitrate at a dose of $30 \mathrm{~kg} / \mathrm{ha}$ in the tillering phase and foliar treatment with urea at a dose of $30 \mathrm{~kg} / \mathrm{ha}$, the highest yield indicators $(2.79 \mathrm{t} / \mathrm{ha})$, grain protein content of $13.12 \%$, the maximum net income, profitability of $92 \%$ and energy efficiency were achieved; the energy efficiency coefficient in crops was the highest, the energy efficiency coefficient in protein was the lowest. 


\section{References}

1. I.N. Zelenin, V.I. Eliseev, A.A. Kurochkin, Bull. of the Altai SAU 10(84), 5 (2011)

2. A.N. Orlov, O.A. Tkachuk, E.V. Pavlikova, Achievements of sci. and techn. of the agroindustrial complex 7, 28-30 (2009)

3. O.L. Saltykova, N.P. Bakaeva, Innov. achievements in sci. and techn. of the agro-industrial complex 161-165 (2018)

4. V.K. Ivchenko, Z.I. Mikhailova, Bull. of Krasnoyarsk State Agrarian University 4(127), 3-10 (2017)

5. S.N. Zudilin, Fundamental and applied principles for maintaining soil fertility and obtaining environmentally friendly crop products 190-196 (2017)

6. V.G. Kutilkin, Agriculture 7, 27-29 (2014)

7. T.I. Brassington, Agric. Engineer 2(42), 53-57 (1987)

8. N.S. Nemtsev, K.I. Karpovich, Agriculture 11, 50-51 (1989)

9. R. Lal, J. of sustainable agriculture 33, 66-87 (2009)

10. G. Kahht, Minimal Boden bearbeitung Verlag 150 (1995)

11. G.I. Cossacks, Soil treatment in the Middle Volga region 196 (1997)
12. V.A. Korchagin, I.A. Chudanov, Modern technological complexes for the cultivation of grain crops in adaptive farming systems Samara Research Institute of Agriculture Volga MIS 28-39 (2002)

13. N.P. Bakaeva, O.L. Saltykova, Manifestation of the protein complex of wheat grains from various agricultural technologies of the Middle Volga region 157 (2018)

14. N.P. Bakaeva, T.D. Giasov, M.T. Khasanov, M.A. Babadzhanova, Arabidopsis Inform. Service 17, 120-122 (1980)

15. B.A. Armor, Field Experiment Methodology 351 (1985)

16. G.I. Rabochev, V.G. Kutilkin, A.L. Rabochev, Bioenergy assessment of technological processes in crop production 112 (2005)

17. V.I. Morozov, A.L. Toygildin, M.I. Posevalov, V.V. Basenkov, Niva of the Volga region 4(41), 4955 (2016)

18. G. Michael, H. Faust, Die Eiweiß bildung im Getreidekorn in Abhängiikeit von der stickstoffdüngung Getreide und Meh 11 (1961)

19. N.P. Bakaeva, Yu.G. Nasyrova, O.L. Saltykova, N.Yu. Korzhavina, O.V. Mamai, Res. J. of Pharmaceutical, Biological and Chemical Sci. 5(9), 1221-1229 (2018)

20. N.P. Bakaev, Bull. of Ulyanovsk State Agricultural Academy 4(44), 71-76 (2018) 